\section{High-dose vecuronium neuromuscular block: a comparison of arrhyth- mias and onset of block during sufentanil anaesthesia}

Michael D. Sharpe MD FRCPC, John M. Murkin MD FRCPC, Tony Vannelli MD FRCPC
This study compared the heamodynamic effects of sufentanil with those observed following concomitant sufentanil and highdose vecuronium administration to determine whether vecuronium induces bradyarrhythmias. Sixty coronary artery bypass patients were stratified into beta blocker $(n=30)$ or non-beta blocker $(n=30)$ groups and following induction with sufentanil $\left(9 \pm 3 \mu \mathrm{g} \cdot \mathrm{kg}^{-1}\right)$ and midazolam (0.07 $\left.\pm 0.04 \mathrm{mg} \cdot \mathrm{kg}^{-1}\right)$, received either succinylcholine $1 \mathrm{mg} \cdot \mathrm{kg}^{-1}$ (SxCh), vecuronium $0.3 \mathrm{mg} \cdot \mathrm{kg}^{-1}$ (Vec 0.3), or vecuronium $0.5 \mathrm{mg} \cdot \mathrm{kg}^{-1}$ ( $\mathrm{Vec} 0.5$ ). Using a Holter ECG monitor, bradyarrhythmias were classified as mild (HR 46-50), moderate (HR 40-45) or severe (HR $<$ 40). In the pre-induction period, there were no differences in the incidence of mild, moderate or severe bradyarrhythmias among the $\mathrm{SxCh}, \mathrm{Vec} 0.3$ or Vec 0.5 groups, in either the beta blocker or non-beta blocker groups. Following induction, there were similar reductions in mean heart rate and mean arterial pressure in all three muscle relaxant groups in both the beta and the non-beta blocker groups; however, there was no difference in the incidence of mild, moderate or severe bradyarrhythmias among the SxCh, Vec 0.3 or Vec 0.5 groups. The Vec 0.5 beta blocker group had a higher incidence of mild bradyarrhythmias (32 $\pm 36 \%$ ) than the Vec 0.5 non-beta blocker group ( $\pm 3 \%, P=0.017)$. Using $E M G$ recording, the onset

\section{Key words}

NEUROMUSCULAR RELAXANTS: succinylcholine,

vecuronium;

ANAESTHESIA: cardiovascular;

ANAESTHETICS, INTRAVENOUS: sufentanil; HEART: arrhythmia, bradycardia.

From the Department of Anaesthesia, University Hospital, University of Western Ontario, London, Ontario, Canada.

Address correspondence to: Dr. M.D. Sharpe, Department of Anaesthesia, University Hospital, 339 Windermere Road, London, Ontario N6A 5A5.

Supported in part by a research grant from Organon Ltd. Accepted for publication Sth April, 1995. time of maximal neuromuscular block for the Vec 0.3 group $(108 \pm 17 \mathrm{sec})$ was longer $(P<0.05)$ than the SxCh $(76 \pm$ $21 \mathrm{sec})$ and Vec $0.5(82 \pm 13 \mathrm{sec})$ groups, which were similar. We conclude: (i) vecuronium does not affect $H R$ or the incidence of bradyarrhythmias following sufentanil administration and that the observed reduction in HR and mean arterial pressure were due to sufentanil administration, (ii) vecuronium $\left(0.5 \mathrm{mg} \cdot \mathrm{kg}^{-1}\right)$ provides an onset time of neuromuscular block similar to SxCh, and (iii) patients taking beta blockers preoperatively are more prone to develop bradyarrhythmias during sufentanil administration.

Cette étude compare les effets hémodynamiques du sufentanil avec ceux qu'on observe après l'administration simultanée de sufentanil et de vécuronium à hautes doses afin de déterminer si le vécuronium provoque des bradyarythmies. Soixante patients soumis à une revascularisation myocardique sont d'abord répartis entre $\beta$-bloqués $(n=30)$ et non $\beta$-bloqués $(n=30)$. Après linduction au sufentanil ( $9 \pm 3 \mu \mathrm{g} \cdot \mathrm{kg}^{-1}$ ) et midazolam $\left(0,07 \pm 0,04 \mathrm{mg} \cdot \mathrm{kg}^{-1}\right)$, ils reçoivent soit de la succinylcholine $1 \mathrm{mg} \cdot \mathrm{kg}^{-1}$ (SxCh), soit du vécuronium $0,3 \mathrm{mg} \cdot \mathrm{kg}^{-1}$ (Vec $0,3)$, soit du vécuronium $0,5 \mathrm{mg} \cdot \mathrm{kg}^{-1}$ (Vec 0,5). Grâce à un moniteur Holter, les bradyarythmies sont classifiées comme légères (Fc 46-50), modérées ( $F c$ 40-45) ou graves $(F c<40)$. Avant linduction, lincidence des bradyarythmies légères, modérées ou graves ne differe pas entre les groupes $\mathrm{SxCh}$, Vec 0,3 et Vec 0,5 tant dans les groupes $\beta$ bloqués que non $\beta$ bloqués. Après l'induction, la baisse de la fréquence cardiaque et de la pression artérielle moyenne est identique dans les trois groupes de myorelaxants à la fois dans les groupe $\beta$ - et non $\beta$-bloqués; lincidence de bradyarythmies légère, modérée et grave ne differe pas entre les groupes $\mathrm{SxCh}$, Vec 0,3 et Vec 0,5 . Le groupe Vec 0,5 $\beta$-bloqué présente une incidence plus élevée de bradyarythmie légère $(32 \pm 36 \%$ ) que le groupe Vec 0,5 non $\beta$-bloqué $(2 \pm 3 \%, P=0,017)$. Sur l'enregistrement de l'EMG, linstallation de la curarisation maximale dans le groupe Vec 0,3 $(108 \pm 17 \mathrm{sec})$ est plus lente $(P<0,05)$ que dans les groupes $\mathrm{SxCh}(76 \pm 21 \mathrm{sec})$ et Vec $0,5(82 \pm 13$ 
sec) qui sont identiques. Nous concluons: i) que le vécuronium n'a pas d'effet sur la Fc ou sur lincidence des bradyarythmies après l'administration de fentanyl et que la baisse observée de la Fc et de la pression artérielle moyenne sont dues à l'administration du sufentanil; ii) que le vécuronium $\left(0,5 \mathrm{mg} \cdot \mathrm{kg}^{-1}\right)$ a le même effet sur le délai dinstallation de la curarisation que la SxCh et iii) que les patients qui prennent des $\beta$ bloquants avant lintervention sont plus susceptibles de développer des bradyarythmies pendant l'administration de sufentanil.

Vecuronium has become a popular nondepolarizing muscle relaxant used during cardiac and non-cardiac surgery due to its haemodynamic stability, intermediate duration of action, and lack of histamine release. ${ }^{1-4}$ However, despite these reports, others have implicated vecuronium as eliciting or exacerbating bradyarrhythmias. ${ }^{5-8}$ Furthermore, administering a high dose of vecuronium $(0.3$ or $0.4 \mathrm{mg} \cdot \mathrm{kg}^{-1}$ ) has been shown to increase the speed of onset of neuromuscular block which may prove beneficial in patients who manifest rigidity following opioid administration. ${ }^{2,9,10}$ Yet, this presumed benefit has not been compared with the proven shortest onset time of succinylcholine. Therefore, we studied the haemodynamic effects and, in particular, the incidence of bradyarrhythmias during concomitant high-dose vecuronium and sufentanil administration in patients undergoing elective coronary artery bypass (CAB) surgery. Also, we compared the speed of onset of neuromuscular block of two different high doses of vecuronium $\left(0.3\right.$ and $\left.0.5 \mathrm{mg} \cdot \mathrm{kg}^{-1}\right)$ with that of succinylcholine.

\section{Methods}

With institutional ethics committee approval and signed patient consent, 60 patients with no known renal/hepatic/ neuromuscular disease undergoing elective coronary artery bypass graft surgery were studied. Patients were enrolled into either a beta blocker or non-beta blocker group determined by whether or not they were taking beta blockers preoperatively, until one-half of the study population ( $n=30$ ) were taking beta blockers and the other half were not. All patients received their morning dose of all cardiac medications on-call to surgery, as well as lorazepam $\left(0.03 \pm 0.02 \mathrm{mg} \cdot \mathrm{kg}^{-1}\right.$, sl). A Holter ECG Monitor recorded heart rate continuously from the time of entry into the operating room until institution of cardiopulmonary bypass. Routine monitors included radial intraarterial line, five lead ECG, pulse oximetry, end tidal $\mathrm{CO}_{2}$, (N-1000, Nelcor Inc., Hayward, California 94345) and nasal/rectal temperature probes. Before induction, a pulmonary artery catheter was inserted via the right internal jugular vein and thermodilution cardiac output was performed. For measurement of neuromuscular block, a Datex NMT 221 monitor (Puritan-Bennett) was used with surface electrodes placed over the hypothenar muscles using train-of-four (TOF) supramaximal stimulation $(2 \mathrm{~Hz})$ to the ulnar nerve. Both upper limbs were then wrapped with insulating padding and tucked at the patient's sides. Anaesthesia was induced with a combination of midazolam $\left(0.7 \pm 0.04 \mathrm{mg} \cdot \mathrm{kg}^{-1}, i v\right)$ and sufentanil $\left(9 \pm 3 \mu \mathrm{g} \cdot \mathrm{kg}^{-1}, i v\right)$. The doses of these medications were at the discretion of the attending anaesthetist. Supplemental doses of sufentanil and midazolam were given to patients at the institution of cardiopulmonary bypass, following completion of our study. Calibration of the neuromuscular monitor occurred following induction and a stable baseline EMG was obtained prior to the administration of the muscle relaxant. The muscle relaxant was rapidly administered as a bolus via a fast flowing peripheral iv line. Patients in each study population ( $n=30$ ), were randomly assigned to one of three groups $(n=10)$ : Group 1: succinylcholine $1 \mathrm{mg} \cdot \mathrm{kg}^{-1}$ (SxCh); Group 2: vecuronium $0.3 \mathrm{mg} \cdot \mathrm{kg}^{-1}$ (Vec 0.3); or Group 3: vecuronium $0.5 \mathrm{mg} \cdot \mathrm{kg}^{-1}$ ( $\mathrm{Vec} 0.5$ ). Larnygoscopy and intubation were not performed until the onset of complete paralysis, as determined by no response to TOF stiumulation. Patients in the succinylcholine groups received vecuronium $(20 \mathrm{mg})$ at the institution of cardiopulmonary bypass, the point at which our study was completed. Positive-pressure ventilation with air/oxygen was used to maintain normocapnia and arterial oxygen saturation $\geq 95 \%$.

\section{Analysis of bradyarrhythmias}

\section{Definitions}

1 Heart rate (HR) was determined as the time-weighted average over one-minute intervals, with an event defined as each one-minute interval. Mean heart rate was calculated as (total heart rate/number of events).

2 Bradyarrhythmias were classified according to heart rate: mild; HR 46-50 beats per minute (bpm); moderate, HR 40-45 bpm; severe, HR $<40 \mathrm{bpm}$.

3 Pre-induction period was the time from entry into the operating room (with application of Holter Monitor) until induction of anaesthesia, and was 20-25 min in duration.

4 Post-induction period was time from onset of maximal neuromuscular block until insertion of aortic and venous cannulas.

To determine whether succinylcholine had any effect on heart rate, the mean heart rate during the period from administration of succinylcholine to maximal neuromuscular block (a two-minute interval) was compared with the mean heart from the time of full recovery (as determined by the EMG), to the point of insertion of the aortic and venous cannulas. 
TABLE I Anthropometric characteristics

\begin{tabular}{llllllll}
\hline & \multicolumn{3}{l}{ Beta blocker group } & & & \multicolumn{3}{l}{ Non-beta blocker group } \\
\cline { 2 - 3 } & SxCh & Vec 0.3 & Vec 0.5 & & SxCh & Vec 0.3 & Vec 0.5 \\
\hline Age (yr) & $67 \pm 7$ & $64 \pm 9$ & $61 \pm 7$ & & $69 \pm 10$ & $64 \pm 9$ & $65 \pm 9$ \\
Wt (kg) & $91 \pm 12$ & $84 \pm 13$ & $74 \pm 14^{*}$ & & $77 \pm 16$ & $79 \pm 14$ & $76 \pm 19$ \\
Sex (m/f) & $10 / 0$ & $10 / 0$ & $8 / 2$ & & $6 / 4$ & $8 / 2$ & $8 / 2$ \\
\hline
\end{tabular}

Mean $\pm S D$.

${ }^{*} P<0.05$, SxCh vs Vec 0.5 (ANOVA).

$\mathrm{SxCh}=$ succinylcholine $1 \mathrm{mg} \cdot \mathrm{kg}^{-\mathrm{l}}$; Vec $0.3=$ vecuronium $0.3 \mathrm{mg} \cdot \mathrm{kg}^{-1} ; \mathrm{Vec} 0.5=$ vecuronium $0.5 \mathrm{mg} \cdot \mathrm{kg}^{-1}$.

5 The incidence (\%) of each bradyarrhythmia was calculated as: (\# of bradyarrhythmia events/total number of events measured in each specified period) $\times 100$.

To assess the potential interaction between sufentanil and vecuronium, the post-induction period in the $\mathrm{SxCh}$ group, from full recovery of the succinylcholine-induced neuromuscular block (return of EMG amplitude to baseline) to the point of insertion of aortic and venous cannulas was compared with that of the sufentanilvecuronium groups over a similar period.

\section{Analysis of onset of neuromuscular block}

The speed of onset of neuromuscular block was measured from the time of administration of the muscle relaxant to the point of maximum neuromuscular block as determined by the continuous EMG recording, which provided an EMG response recording every ten seconds. Prior to the administration of the muscle relaxant, a stable neuromuscular response to TOF stimulation was confirmed.

\section{Statistical analysis}

Statistical analysis was performed separately for the beta blocker and non-beta blocker groups. Within each of these groups, analysis of variance (ANOVA) was used to compare anthropometric data, mean doses of anaesthetic drugs, cardiac index, and onset times of neuromuscular block among the three muscle relaxant groups. Similarly, ANOVA was used to compare mean heart rate and incidence of mild, moderate and severe bradyarrhythmias, among muscle relaxant groups, for the preinduction period, and similarly for the post-induction period. When statistical significance was achieved, the student Newman Keuls test was used to determine which interaction was significant, defined as $P<0.05$. Paired Student's $t$ test was used to compare mean heart rate and blood pressure before and following induction of anaesthesia, within each muscle group. Chi Square Analysis was used to determine whether the distribution of patients taking calcium channel blockers was similar among the three muscle relaxant groups, in both the beta blocker and non-beta blocker groups.

To assess for potential influence of beta blockers on HR and the incidence of bradyarrhythmias, unpaired Student's $t$ tests were used to compare the mean heart and incidence of bradyarrhthmias for each muscle relaxant group between the beta and non-beta blocker groups, at pre- and post-induction periods.

All results are expressed as mean $\pm \mathrm{SD}$. Results for which no change was detected underwent post-hoc testing for the probability of a Type II error using a beta value of $<0.10$ and a clinical significant difference of $20 \%$, using the power of a test of significance equation."

\section{Results}

The anthropometric characteristics of the beta blocker and non-beta blocker groups are shown in Table I. The mean weight of the vecuronium 0.5 beta blocker group was lower than that of the succinylcholine group $(P<$ 0.05 ). Calcium channel blockers were prescribed to $80 \%$ and $70 \%$ of patients in the beta blocker and non-beta blocker groups, respectively, and these patients were evenly distributed throughout the three muscle relaxant groups.

The mean premedication dose of lorazepam, and mean induction doses of midazolam and sufentanil are listed in Table II. The mean dose of each agent was similar in all three muscle relaxant groups in both the beta and non-beta blocker patient groups.

The effects of sufentanil/midazolam anaesthesia on mean blood pressure (MAP), mean heart rate (HR) and cardiac index (Cl) are shown in Table III. There were no differences in pre-induction haemodynamic values among the muscle relaxant groups in both the beta and non-beta blocker groups. A similar decrease in HR occurred following induction of anaesthesia within all three muscle relaxant groups in both the beta blocker and nonbeta blocker groups. The post-induction HR was similar during succinylcholine neuromuscular block as the $\mathrm{HR}$ measured following recovery from succinylcholine, in 
TABLE II Dose of anaesthetic agents

\begin{tabular}{|c|c|c|c|c|c|c|}
\hline & \multicolumn{3}{|c|}{ Beta blocker group } & \multicolumn{3}{|c|}{ Non-beta blocker group } \\
\hline & $S x C h$ & $\operatorname{Vec} 0.3$ & $\operatorname{Vec} 0.5$ & SxCh & Vec 0.3 & $\operatorname{Vec} 0.5$ \\
\hline Lorazepam (mg · $\left.\mathrm{kg}^{-1} ; \mathrm{sl}\right)$ & $0.03 \pm 0.01$ & $0.04 \pm 0.01$ & $0.04 \pm 0.02$ & $0.04 \pm 0.02$ & $0.03 \pm 0.02$ & $0.03 \pm 0.02$ \\
\hline Midazolam (mg $\cdot \mathrm{kg}^{-1}$, iv) & $0.06 \pm 0.03$ & $0.06 \pm 0.04$ & $0.07 \pm 0.04$ & $0.07 \pm 0.03$ & $0.05 \pm 0.02$ & $0.08 \pm 0.05$ \\
\hline Sufentanil $\left(\mu \mathrm{g} \cdot \mathrm{kg}^{-1} ;\right.$ iv) & $8 \pm 3$ & $7 \pm 2$ & $8 \pm 4$ & $9 \pm 4$ & $7 \pm 4$ & $10 \pm 3$ \\
\hline
\end{tabular}

Mean $\pm S D$.

$\mathrm{SxCh}=$ succinylcholine $1 \mathrm{mg} \cdot \mathrm{kg}^{-1}$; Vec $0.3=$ vecuronium $0.3 \mathrm{mg} \cdot \mathrm{kg}^{-1} ;$ Vec $0.5=$ vecuronium $0.5 \mathrm{mg} \cdot \mathrm{kg}^{-1}$.

TABLE III Effects of sufentanil-midazolam-muscle relaxant anaesthesia on haemodynamic variables

\begin{tabular}{|c|c|c|c|c|c|c|c|c|}
\hline & \multicolumn{4}{|c|}{ Beta blocker group } & \multicolumn{4}{|c|}{ Non-beta blocker group } \\
\hline & SxCh & & $\operatorname{Vec} 0.3$ & $\operatorname{Vec} 0.5$ & $S x C h$ & & $\operatorname{Vec} 0.3$ & $\operatorname{Vec} 0.5$ \\
\hline HR (bpm) & & & & & & & & \\
\hline $\begin{array}{l}\text { - pre-induction } \\
\text { - post-induction }\end{array}$ & $\begin{array}{l}67 \pm 15 \\
58 \pm 14 \dagger \\
(\mathrm{SxCh}) \\
\text { effects }\end{array}$ & $\begin{array}{l}58 \pm 15 \dagger \\
(\mathrm{SxCh}) \\
\text { recovery }\end{array}$ & $\begin{array}{l}62 \pm 9 \\
54 \pm 5 \dagger\end{array}$ & $\begin{array}{l}69 \pm 15 \\
59 \pm 18 \dagger\end{array}$ & $\begin{array}{l}\quad 71 \pm 15 \\
55 \pm 13^{*} \\
(\mathrm{SxCh}) \\
\text { effects }\end{array}$ & $\begin{array}{l}56 \pm 13^{*} \\
(\mathrm{SxCh}) \\
\text { recovery }\end{array}$ & $\begin{array}{l}65 \pm 6 \\
55 \pm 13^{*}\end{array}$ & $\begin{array}{l} \pm 70 \pm 10 \\
62 \pm 13^{*}\end{array}$ \\
\hline $\begin{array}{l}\text { MAP (mmHg) } \\
\text { - pre-induction } \\
\text { - post-induction }\end{array}$ & $\begin{array}{l}86 \pm 4 \\
75 \pm 7\end{array}$ & & $\begin{array}{l}89 \pm 9 \\
77 \pm 11 \S\end{array}$ & $\begin{array}{l}79 \pm 9 \\
66 \pm 138\end{array}$ & $\begin{array}{l}88 \pm 10 \\
72 \pm 8 \dagger\end{array}$ & & $\begin{array}{l}93 \pm 9 \\
78 \pm 9 \ddagger\end{array}$ & $\begin{array}{l}91 \pm 11 \\
76 \pm 8^{*}\end{array}$ \\
\hline $\begin{array}{l}\mathrm{Cl}\left(\mathrm{L} \cdot \min ^{-1} \cdot \mathrm{m}^{-2}\right) \\
\text { - pre-induction }\end{array}$ & $2.12 \pm 0.42$ & & $2.07 \pm 0.43$ & $2.19 \pm 0.52$ & $2.40 \pm 0.52$ & & $2.37 \pm 0.53$ & $2.78 \pm 0.60$ \\
\hline
\end{tabular}

Mean \pm SD.

$* P<0.005$.

$+P<0.001$.

$\ddagger P<0.05$;

$\S P<0.01 ;$ pre vs post-induction (paired Student's $t$ test).

$\mathrm{SxCh}$ effects $=$ mean HR measured at point of maximum block of succinylcholine; SxCh recovery $=$ mean HR measured at point of full recovery of succinylcholine block; bpm = beats per minute; $\mathrm{SxCh}=$ succinylcholine $1 \mathrm{mg} \cdot \mathrm{kg}^{-1} ; \mathrm{Vec} 0.3=$ vecuronium $0.3 \mathrm{mg} \cdot \mathrm{kg}^{-1} ; \mathrm{Vec} 0.5=$ vecuronium $0.5 \mathrm{mg} \cdot \mathrm{kg}^{-1}$.

both the beta blocker ( $58 \pm 14 \mathrm{bpm} \rightarrow 58 \pm 15)$ and non-beta blocker $(55 \pm 13 \rightarrow 56 \pm 13)$ groups $(\beta$ error $<0.10$ ). Furthermore, comparison of HR between the beta and non-beta blocker groups for each muscle relaxant was similar at pre- and post-induction periods $(\beta$ error $<0.10$ ). There was a similar reduction in MAP among the muscle relaxant groups, following in induction of anaesthesia, in both the beta and non-beta groups. The CI was similar in all groups of patients.

The incidences of bradyarrhythmias for each muscle relaxant group are shown in Table IV. There was no difference in the incidences of mild, moderate or severe bradyarrythmias among the three muscle relaxant groups at the pre-induction or post-induction periods (ANOVA) in either the beta or non-beta blocker groups. Furthermore, comparison among the three muscle relaxant groups of the overall incidences of bradyarrythmias (combining mild, moderate and severe incidences) during the pre-induction period as well as the post-induction period, revealed no differences in either the beta blocker or nonbeta blocker groups. However, comparison between the beta and non-beta blocker groups revealed a higher incidence of mild bradyarrhythmias in the Vec 0.5 beta blocker group than in the Vec 0.5 non-beta blocker group, post-induction $(P=0.017)$.

Since there were no differences in $\mathrm{Cl}$ between the beta and non-beta blocker groups (ANOVA), the times for onset of neuromuscular block for the beta and non-beta blocker groups were pooled for each muscle relaxant group. Onset times for four patients in the SxCh group and for seven patients in the Vec 0.3 group were not recorded due to technical difficulties. The onset times for the remaining patients are shown in Table V. The onset time for vecuronium $\left(0.3 \mathrm{mg} \cdot \mathrm{kg}^{-1}\right)$ was longer than that of succinylcholine or vecuronium $\left(0.5 \mathrm{mg} \cdot \mathrm{kg}^{-1}\right)$. The onset times for succinylcholine and vecuronium $(0.5$ 
TABLE IV Incidence of (\%) of bradyarrhythmias pre- and postinduction with sufentanil-midazolam muscle relaxant anaesthesia*

\begin{tabular}{lcll}
\hline & $\begin{array}{c}\text { Mild (\%) } \\
(46-50 \mathrm{bpm})\end{array}$ & $\begin{array}{c}\text { Moderate (\%) } \\
(40-45 \mathrm{bpm})\end{array}$ & $\begin{array}{l}\text { Severe (\%) } \\
(<40 \mathrm{bpm})\end{array}$ \\
\hline $\begin{array}{l}\text { Beta blocker group } \\
\text { SxCh }(n=10)\end{array}$ & & & \\
- pre-induction & $14 \pm 30$ & $2 \pm 5$ & 0 \\
- post-induction & $9 \pm 16$ & $16 \pm 35$ & $2 \pm 6$ \\
Vec 0.3 ( $n=10)$ & & & \\
- pre-induction & $8 \pm 26$ & $6 \pm 19$ & 0 \\
- post-induction & $33 \pm 36$ & $6 \pm 10$ & 0 \\
Vec 0.5 ( $n=10)$ & & & \\
- pre-induction & 0 & 0 & 0 \\
- post-induction & $32 \pm 36$ & $18 \pm 29$ & 0 \\
Non-beta blocker group & & \\
SxCh $(n=10)$ & & & \\
- pre-induction & $6 \pm 9$ & 0 & 0 \\
- post-induction & $21 \pm 32$ & $16 \pm 27$ & $4 \pm 13$ \\
Vec $0.3(n=10)$ & & & \\
- pre-induction & 0 & 0 & 0 \\
- post-induction & $31 \pm 40$ & $1 \pm 4$ & 0 \\
Vec $0.5(n=10)$ & & & \\
- pre-induction & $3 \pm 12$ & 0 & 0 \\
- post-induction & $2 \pm 3$ & $8 \pm 23$ & $2 \pm 6$ \\
\hline
\end{tabular}

$*(\%)=(\#$ of bradyarrhythmia events/total \# of events $) \times 100$. $\mathrm{bpm}=$ beats per minute; $\mathrm{SxCh}=$ succinylcholine $1.0 \mathrm{mg} \cdot \mathrm{kg}^{-1} ; \mathrm{Vec}$ $0.3=$ vecuronium $0.3 \mathrm{mg} \cdot \mathrm{kg}^{-1}$; Vec $0.5=$ vecuronium $0.5 \mathrm{mg} \cdot \mathrm{kg}^{-1}$.

TABLE V Onset times for maximal neuromuscular block (Tmax)

\begin{tabular}{llcl}
\hline & $S x C h$ & $\operatorname{Vec} 0.3$ & $\operatorname{Vec} 0.5$ \\
\hline$n$ & 16 & 13 & 20 \\
$T \max (\mathrm{sec})$ & $76 \pm 21$ & $108 \pm 17^{*} \dagger$ & $82 \pm 13$ \\
\hline
\end{tabular}

Mean \pm SD.

$* P<0.05$, Vec 0.3 vs SxCh (ANOVA).

$\dagger P<0.05$, Vec 0.3 vs Vec 0.5 (ANOVA).

$\mathrm{SxCh}=$ succinylcholine $1 \mathrm{mg} \cdot \mathrm{kg}^{-1}$; Vec $0.3=$ vecuronium 0.3

$\mathrm{mg} \cdot \mathrm{kg}^{-\mathrm{I}} ; \mathrm{Vec} 0.5=$ vecuronium $0.5 \mathrm{mg} \cdot \mathrm{kg}^{-1}$.

$\left.\mathrm{mg} \cdot \mathrm{kg}^{-1}\right)$ were similar $(76 \pm 21$ vs $82 \pm 13 \mathrm{sec}$, respectively, $\beta$ error $<0.10$ ). All patients demonstrated four twitches in response to TOF stimulation at the end of surgery.

\section{Discussion}

This study demonstrates that the administration of highdose vecuronium (doses: $0.3 \mathrm{mg} \cdot \mathrm{kg}^{-1}$ and $0.5 \mathrm{mg} \cdot \mathrm{kg}^{-1}$ ) does not influence mean heart rate or the incidence of bradyarrhythmias compared to succinylcholine during high-dose sufentanil anaesthesia in CAB patients. However, patients taking beta blockers preoperatively had a higher incidence of mild bradyarrhythmias following sufentanil administration. As well, the onset time of neuromuscular block following vecuronium $\left(0.5 \mathrm{mg} \cdot \mathrm{kg}^{-1}\right)$ is similar to that achieved with succinylcholine.

Despite numerous studies indicating the haemodynamic stability following vecuronium administration, several reports have implicated vecuronium as causing bradyarrhythmias during both cardiac and non-cardiac procedures. ${ }^{5-8}$ However, what is not clear from these reports is whether the bradyarrhythmic events were due to vecuronium administration or due to the effects of opioid administration and/or various stimuli which are known to increase vagal activity (e.g., mesenteric traction, cervical dilatation). ${ }^{12,13}$ For example, Starr et al. ${ }^{6}$ reported three patients, all of whom were taking beta blockers preoperatively, who developed bradyarrhythmias following induction with high-dose sufentanil and vecuronium; one patient became asystolic during laryngoscopy, a known potent vagotonic stimulus. ${ }^{13}$ Clayton? describes a patient undergoing laparoscopy during enfluranevecuronium anaesthesia who became bradycardic during dilatation of the cervix and insufflation of the abdomen with carbon dioxide; both stimuli are capable of eliciting bradyarrhythmias. ${ }^{13}$ This patient had also received an opioid pre-medication. As well, studies have compared the heart rate effects of vecuronium with other muscle relaxants during opioid administration and have demonstrated lower heart rates in the vecuronium groups compared with other muscle relaxants which are known to have vagolytic activity (e.g., pancuronium, alcuronum), thereby implying that vecuronium elicits bradyarrhythmias. ${ }^{4,5,8,14,15}$

Morton et al. studied 20 patients undergoing enfluranemorphine anaesthesia who were randomized to receive either vecuronium or alcuronium. ${ }^{5}$ Five episodes of bradycardia occurred in the vecuronium group while none occurred with alcuronium. Salmenpera et al. ${ }^{8}$ studied the heart rate effects of vecuronium compared with those of pancuronium during high-dose fentanyl anaesthesia for $\mathrm{CAB}$ surgery. The pancuronium group had a higher heart rate than the vecuronium group which is not surprising due to pancuronium's effects at the autonomic ganglion. It not only elicits vagolytic activity due to muscarinic receptor stimulation, but also facilitates norepinephrine release and blockade of norepinephrine uptake at the sympathetic pre-synaptic nerve terminal which may also elicit vagolytic effects. ${ }^{16,17}$ Vecuronium, on the other hand, a monoquaternary analogue of pancuronium, does not effect norepinephrine release/uptake and it has no muscarinic or ganglionic receptor activity. As a result, no effect on heart rate is anticipated. Therefore, it is unclear whether the bradyarrhythmia events associated with opioid-vecuronium administration are solely due to the 
sympatholytic effects of opioids, or whether vecuronium elicits parasympathomimetic activity.

Animal data studying the pharmacodynamic effects of vecuronium support the hypothesis that vecuronium has no effect on heart rate. Marshal et al. administered up to 20 times the dose required for neuromuscular block in cats and dogs and found no changes in heart rate either by vecuronium or its active metabolites. ${ }^{18}$ Sutherland et al. supported this conclusion in a separate cat study. ${ }^{19}$ Booij administered three times $\mathrm{ED}_{90}$ in dogs and found no change in heart rate, blood pressure or cardiac output. ${ }^{20}$ They concluded that vecuronium has no effect on heart rate; however, its lack of vagolytic activity may allow bradyarrhythmias to occur more easily during surgery, whether drug or reflex induced. In humans, administration of vecuronium during halothane or enflurane anaesthesia had no effect on heart rate. ${ }^{21,22}$ Cozanitis $e t$ al. ${ }^{23}$ concluded, in the absence of surgical stimuli or vagotonic drugs, that vecuronium does not alter heart rate during general anaesthesia. Although substantial evidence exists in both humans and animals that vecuronium does not alter heart rate, none of these studies compared the effects of vecuronium administration during a high-dose opioid anaesthetic with a similar opioid anaesthtetic without a muscle relaxant. Therefore, we developed a protocol which would allow us to compare the effects on heart rate and incidence of bradyarrhythmias of a high-dose opioid anaesthetic with those effects of a combined highdose opioid anaesthetic with vecuronium. As well, we carried out the study in patients who were receiving beta blockers preoperatively as well as in a group of patients who were not, to determine if beta blocker administration influenced susceptibility to bradyarrhythmias.

Our results demonstrated that in both the beta blocker and non-beta blocker groups of patients there was a similar reduction in mean heart rate in the SxCh group as in the two vecuronium groups, after induction of anaesthesia with sufentanil. The incidences of mild (46-50 bpm), moderate $(40-45 \mathrm{bpm})$ and severe $(<40 \mathrm{bpm})$ bradyarrhythmias were also similar in the pre- and postinduction periods among the three muscle relaxant groups ( $\beta$ error $<0.50$ ). Furthermore, when the combined incidence of all bradyarrhythmias (mild + moderate + severe) was calculated and compared among the three muscle relaxant groups, no difference was detected during the pre-induction periods ( $\beta$ error $<0.15$ ). The results imply that, since the reductions in heart rate seen in the vecuronium groups were similar to those in the SxCh group, the reductions in heart rate were due to the sympatholytic effects of sufentanil and that vecuronium had no influence upon these bradyarrhythmias.

The limitations of our bradyarrhythmia data are twofold. First, we assume that once full twitch recovery had occurred, the cardiovascular side effects of succinylcholine (for example, its potential to cause bradyarrhythmias) have dissipated. The validity of this assumption is not known but we know of no evidence which demonstrates the persistence of cardiovascular side effects following full recovery of neuromuscular block due to a single administration of succinylcholine. Furthermore, we were not anticipating a high incidence of bradyarrhythmias following single dose succinylcholine administration as this has been demonstrated to occur in less than three percent of patients. ${ }^{24}$ The propensity of succinylcholine to elicit bradyarrhythmias is following second dose adminstration. Also, the period of vulnerability to bradyarrhythmias following the first dose administration of succinylcholine, has not been documented. Second, although the incidences of bradyarrhythmias were similar among the muscle relaxant groups in both the beta blocker and non-beta blocker groups (Table V), the variation of bradyarrhythmias within each group were in some instances quite large. Thus, when combined with a small sample size $(n=10)$, a large $\beta$ error occurred $(\beta<0.05)$, indicating the possibility of a false negative result. However, when the incidences of all bradyarrhythmias were combined (mild + moderate + severe) and compared among the three muscle relaxant groups, no difference appeared with a $\beta$ error $<0.15$ in either the beta blocker and non-beta blocker groups. Furthermore, the mean heart rate data also did not detect any difference among the various muscle relaxant groups $(\beta$ error $<0.10$ ), in either the beta or non-beta blocker groups.

Following induction with sufentanil, there was a comparable reduction in mean arterial pressure among the three muscle relaxant groups in both the beta blocker and non-beta blocker groups, suggesting vecuronium had no influence upon this variable, either.

This study also investigated the effects of increasing the dose of vecuronium on onset time of neuromuscular block. Several investigators have shown that increasing the intubating dose of vecuronium will shorten the time of onset significantly. Tullock et al. studied $\mathbf{4 0}$ adult patients and found that increasing the dose from 0.1 to $0.4 \mathrm{mg} \cdot \mathrm{kg}^{-1}$ decreased the onset time from $164 \pm 27$ to $78 \pm 19 \mathrm{sec}^{2}$ Furthermore, there were no dose-related changes in blood pressure, heart rate or histamine release following vecuronium administration. Casson et al. $.^{5} \mathrm{dem}-$ onstrated a remarkable onset time of $43 \pm 11 \mathrm{sec}$ following $0.4 \mathrm{mg} \cdot \mathrm{kg}^{-1}$ of vecuronium. It is important to note, however, that their definition of onset time was measured when the depression of the first twitch was $\geq 95 \%$ of control which may have contributed to the shorter onset time, whereas we measured the time required for complete neuromuscular block (e.g., no EMG response to TOF stimulation). However, these studies did 
not compare the onset times with those of succinylcholine in the same patient population, ${ }^{2,9,10}$ so that to conclude that high-dose vecuronium has onset times comparable with succinylcholine is inappropriate.

There are many factors which influence the onset of action of muscle relaxants. Muscle relaxants are usually administered intravenously. Therefore, cardiac output and muscle blood flow are major factors that affect the delivery time of the muscle relaxant to the neuromuscular junction. Curran et al. have also demonstrated that increasing the duration of train-of-four stimulation prior to administration of a muscle relaxant decreased the onset time, presumably by augmenting blood flow to the stimulated muscle. ${ }^{25}$ Other factors include affinity of the muscle relaxant to the muscle, rate of diffusion into the synaptic cleft and binding of the muscle relaxant to the acetylcholine receptor, ${ }^{26}$ all of which are not controllable. Thus, we elected to include a succinylcholine group for comparison with the Vec 0.3 and Vec 0.5 groups to control for the many factors that influence onset of action. Also, the calibration of train-of-four stimulation prior to adminstration of the muscle relaxant was similar in all patients (2-3 minutes).

Since CI was similar in all three muscle groups (Table III), we combined the speed of onset data of the beta blocker and non-beta blocker groups. In our study, increasing the dose of vecuronium from $0.3 \mathrm{mg} \cdot \mathrm{kg}^{-1}$ to $0.5 \mathrm{mg} \cdot \mathrm{kg}^{-1}$ reduced onset time from $108 \pm 17$ to 82 $\pm 13 \mathrm{sec}$, which was similar to that of succinylcholine, $1 \mathrm{mg} \cdot \mathrm{kg}^{-1}(76 \pm 21 \mathrm{sec})$. Therefore, administration of high-dose vecuronium $\left(0.5 \mathrm{mg} \cdot \mathrm{kg}^{-1}\right)$ may be beneficial in patients where a rapid onset of muscle paralysis is recommended i.e., full stomach or those who exhibit significant "rigidity" following opioid administration. Furthermore, vecuronium will not effect heart rate or mean blood pressure.

Succinylcholine has also been implicated to elicit or exacerbate bradyarrhythmias during its administration, particularly following repeated administration. Comparison of the mean heart rate during the two minute period of succinylcholine-induced neuromuscular block with that in the period following recovery of neuromuscular function, indicated no change in HR in either the beta blocker or non-beta blocker groups. Although our conclusions are limited by our small sample size, these data suggest that single dose succinylcholine does not influence the incidence or severity of bradyarrhythmias which may occur following opioid administration. Our results are similar to those observed by Stoelting et al. who demonstrated in 40 patients the incidence of bradyarrhythmias following single dose succinylcholine $\left(1 \mathrm{mg} \cdot \mathrm{kg}^{-1}\right)$ to be $<3 \% .{ }^{24}$

In summary, during high-dose sufentanil $(9 \pm 3$ $\mu \mathrm{g} \cdot \mathrm{kg}^{-1}$ ) anaesthesia for $\mathrm{CAB}$ surgery, high-dose vecuronium $\left(0.3\right.$ or $\left.0.5 \mathrm{mg} \cdot \mathrm{kg}^{-1}\right)$ does not affect mean heart rate or the incidence of bradyarrhythmias compared with succinylcholine administration and that changes in these variables are due to opioid administration. However, patients who are taking beta blockers preoperatively are more likely to develop bradyarrhythmias following sufentanil administration. A combination of high-dose vecuronium and sufentanil anaesthesia provides a haemodynamically stable anaesthetic. The administration of vecuronium $\left(0.5 \mathrm{mg} \cdot \mathrm{kg}^{-1}\right)$ provides an onset time of complete neuromuscular block which is similar to that of succinylcholine.

\section{References}

1 Morris RB, Cahalan MK, Miller RD, Wilkinson Pl, Quasha $A L$, Robinson $S L$. The cardiovascular effects of vecuronium (ORG NC45) and pancuronium in patients undergoing coronary artery bypass grafting. Anesthesiology 1983; 58: 438-40.

2 Tullock WC, Diana P, Cook DR, et al. Neuromuscular and cardiovascular effects of high-dose vecuronium. Anesth Analg 1990; 70: 86-90.

3 Cannon JE, Fahey MR, Moss J, Miller RD. Large doses of vecuronium and plasma histamine concentrations. Can $\mathrm{J}$ Anaesth 1988; 35: 350-3.

4 Paulissian $R$, Mahdi $M$, Joseph NJ, Salem MR, Pavlovich $B$, Crystal GJ. Hemodynamic responses to pancuronium and vecuronium during high-dose fentanyl anesthesia for coronary artery bypass grafting. J Cardiothorac Vasc Anesth 1991; 5: 120-5.

5 Morton CPJ, Drummond GB. Bradycardia and vecuronium: comparison with alcuronium during cholecystectomy. Br J Anaesth 1992; 68: 619-20.

6 Starr NJ, Sethna DH, Estafanous FG. Bradycardia and asystole following the rapid administration of sufentanil with vecuronium. Anesthesiology 1986; 64: 521-3.

7 Clayton D. Asystole associated with vecuronium (Letter). Br J Anaesth 1986; 58; 937-8.

8 Salmenperä M, Peltola K, Takkunen $O$, Heinonen $J$. Cardiovascular effects of pancuronium and vecuronium during high-dose fentanyl anesthesia. Anesth Analg 1983; 62: 1059-64.

9 Casson WR, Jones RM. Vecuronium induced neuromuscular blockade. The effect of increasing dose on speed of onset. Anaesthesia 1986; 41: 354-7.

10 Chen BB, Nyhan DP, Blanck TJJ. Hemodynamic effects and onset time of increasing doses of vecuronium in patients undergoing myocardial revascularization. J Cardiothorac Vasc Anesth 1991; 5: 569-73.

11 Snedecor GW, Cochran WG. Statistical Methods, 7th ed. Ames, Iowa: The Iowa State University Press, 1980: 68-70.

12 Cozanitis DA, Pouttu J, Rosenburg PH. Bradycardia as- 
sociated with the use of vecuronium. A comparative study with pancuronium with and without glycopyrronium.

Anaesthesia 1987; 42: 192-4.

13 Rogers $M C$. Diagnosis and treatment of intraoperative cardiac dysrhythmias. In: Miller Rd (Ed.). Anesthesia, 2nd ed. New York: Churchill Livingston Inc., 1986: 499-521.

14 Waldmann CS, Wark KJ, Sebel PS, Feneck RO. Hemodynamic effects of atracurium, vecuronium and pancuronium during sufentanil anesthesia for coronary artery bypass. Acta Anaesthesiol Scand 1986; 30: 351-6.

15 Dhamee MS, Olund T, Reynolds AC, Entress J, Kalbfleish $J$. Cardiovascular effects of pancuronium, vecuronium, and atracurium during induction of anesthesia with sufentanil and lorazepam for myocardial revascularization. $\mathbf{J}$ Cardiothorac Vasc Anesth 1990; 4: 336-9.

16 Saxena $P R$, Bonta $I L$. Mechanism of selective cardiac vagolytic action of pancuronium bromide. Specific blockade of cardiac muscarinic receptors. Eur J Pharmacol 1970; 11: 332-41.

17 Feuerstein G. The opioid system and central cardiovascular control: analysis of controversies. Peptides 1985; 6(Supp 2): 51-6.

18 Marshall IG, Gibb AJ, Durant NN. Neuromuscular and vagal blocking actions of pancuronium bromide, its metabolites, and vecuronium bromide (ORG NC45) and its potential metabolites in the anaesthetized cat. $\mathrm{Br} \mathrm{J}$ Anaesth 1983; 55: 703-14.

19 Sutherland GA, Squire IB, Gibb AJ, Marshall IG. Neuromuscular blocking and autonomic effects of vecuronium and atracurium in the anaesthetized cat. $\mathrm{Br} \mathrm{J}$ Anaesth 1983; 55: 1119-26.

20 Booij LHDJ, Edwards RP, Sohn YJ, Miller RD. Cardiovascular and neuromuscular effects of Org NC 45, pancuronium, metocurine, and $d$-tubocurarine in dogs. Anesth Analg 1980; 59: 26-30.

21 Engbaek J, Ording H, Sørensen B, Viby-Mogensen J. Cardiac effects of vecuronium and pancuronium during halothane anaesthesia. Br J Anaesth 1983; 55: 501-5.

22 Gregoretti SM, John YJ, Sia RL. Heart rate and blood pressure changes after ORG NC45 (vecuronium) and pancuronium during halothane and enflurane anesthesia. Anesthesiology 1982; 56: 392-5.

23 Cozanitis DA, Erkola $O$. A clinical study into the possible bradycardic activity of vecuronium. Anaesthesia 1989; 44: 648-50.

24 Stoelting RK, Peterson $C$. Heart-rate slowing and junctional rhythm following intravenous succinylcholine with and without intramuscular atropine preanesthetic medication. Anesth Analg 1975; 54: 705-9.

25 Curran MJ, Donati F, Bevan DR. Onset and recovery of atracurium and suxamethonium-induced neuromuscular blockade with simultaneous train-of-four and single twitch stimulation. Br J Anaesth 1987; 59: 989-94.
26 Donati $F$. Onset of action of relaxants. Can J Anaesth 1988; 35: S52-8. 